\title{
EXTERNAL AND INTERNAL SECURITY DIMENSIONS OF EARLY SLAVIC STATHOODS IN THE TERRITORY OF SLOVAKIA
}

\author{
Juraj ŠIMKO \\ Armed Forces Academy of General Milan Rastislav Štefánik, Liptovský Mikuláš, \\ Slovakia \\ juraj.simko@aos.sk
}

\begin{abstract}
The article deals with basic characteriristic of external and internal security of first slavic tribes settled in Middle Europe. It describes struggle against external enemies which were Avarian nomadic tribes in the $7^{\text {th }}$ century. It also describes defense against East Francia in the $9^{\text {th }}$ century, importance of fortificated settlements. It characterizes warrior groups as main element of defence. Third part focuses on basic elements of Gret Moravian's internal security such as law codex named "Law codex for people".
\end{abstract}

Keywords: Early slavic states, Great Moravia, Slavic tribes, Avars, Charlemagne, duke Svätopluk, early slavic law, slavic expansion.

\section{Introduction}

This article indicates the dimensions of the development of the external and internal security of our Slavic ancestors. It is based on research and an analysis of available written sources [1]. As it is a rather broad and wide topic, it is focused on the brief approach and characteristics of the studied subject. Despite of the extensive archaeological research of Slavic settlement in the Slovak Republic area, the issue of securing the internal and external security of the first Slavic state services deserves more detailed processing.

Even today, Slovak society has to deal with the spreading myths of our Slavic ancestor's nature, which depict the Slavs as a dovelike nation, reaching for the weapon only at the time of the greatest threat. However, these are kind of the romanticized ideas of tendentious authors from the period of Slovak national revival (in $19^{\text {th }}$ century). Researches based on historical sources, on the contrary, attest to the fact that the Slavs in the very beginning of their existence in the geopolitical space of the Middle Europe were active participants of the processes leading to the formation of state services, which we cannot call peaceful in any case. Slavs, that were settled in the territory of today's Slovakia, have become political competitors of the surrounding state units, whereby they were defending their way of life, customs, traditions, facilities of production and territory.

In addition to archaeological material pointing to a different culture of the newly arrived population, the contemporary written sources of the Nations retain the migratory current to which the Slavs have gone beyond. It follows, that the Slavs inhabited today's Slovak territory in the first half of the $6^{\text {th }}$ century [2], at which the sources of the previous $5^{\text {th }}$ century do not mention Slavs by the descriptive 
movements of different ethnicities in this area, that excludes the ancestry of the Slavs in our territory.

The settlement of the Slavic ethnicity in the neighbourhood of the Germanic tribes represented not only a new cultural element stream, but also the formation of politicalmilitary interactions accompanying the efforts of territorial expansion. In terms of them, the nomadic Avars start to penetrate to the Carpathian fold at the end of the $6^{\text {th }}$ century and they try to put the local population under their control, which complicates the ethnic relations in this region even more. This confirms that the character of threads and challenges affecting security, is derived from the wider international context. This is characterized by the instability and uncertainty of the overall processes and the complaints of the factors. [3]

However, the origin of the Avarian khaganate did not affect all the Slavs. Only the Slavs living on the northern edge of the avaricious domain were submitted. To the north of Avarian dominance, the density and extension of Slavic settlement and also its economic strength expanded. There was a breakdown of the Slavic society's tribal establishment, even though they were gradually taking over the model of a company organization typical for Western Europe, more precisely the Franconian Empire. It is interesting, that during this process, Slavs, who gained their position in the Carpathian fold before the Avaric arrival, militarily helped Avaric to establish the khaganate. They actively participated in the Avarian-Byzantine wars or in the Avarian conflicts against the Franconian Empire.

\section{The Dimensions of the Development of the External Security among the Slavs in the Pre-Great Moravian Period}

Avarian despotism and intolerance caused a wave of averse among the conquered Slavs. The result was the beginning of a Slavic upper base union in the middle Danube, known as Samo's Empire.

Written sources, such as Fredegar's Chronicle, inform us about the forms of domination among Avaris and Slavs. They describe how Avars exploited the local Slavic population, forcibly adopted agricultural products, and also Avarian warriors forced coexistence with Slavic women. From these forced relations came a layer of population that was not accepted either by the Slavs and the Avars as well, as they were mix blooded. These mix blooded people were outside of the traditional family alliances, they were disinherited, and only military service was possible option for them. They fought in the toughest places, mostly as so-called befulci (subman, rightless warriors). Thus, an organized layer of warriors grew up in the middle of the Slavic Peasant Society [4].

Avarian violence resulted in the outbreak of rebellion against Avarian domination, and its main military force, was the already mentioned group of the warriors. The Franconian merchant Sam, who was a foreigner, joined the rebellion, and was chosen as a king due to the successful struggle of the Slavs. His empire became an important power-political element in the Carpathian fold in the years 623-658. Samo's empire military force has grown so much that the Serbian tribes of Dervan's princedom, and Czechs as well, have been joined to it as cobelligerents. For the first time in the history of the Slavs settled in our territory, we can talk about the successful military actions by which main aim was the security of their own generations as well as expansion of their domain.

In addition to the temporary elimination [5] of the Avarian threat over the Danubian Slavs, this over based system had to face further external threats. The rise of the military potential of the Slavs and their territorial expansion have come to against to the Franconian Empire. In the year 631, the Franconian military struggle against 
Samo's reign is marked, which the Slavs managed to break off (the famous battle at Wogastisburg), and in the following period they carried out robber rides to neighbouring Thuringia. Although we do not have reports about the detailed way in which we can defend ourselves against external threats, it is possible to assume a level of military organization based on reports of military missions to neighbouring regions, providing not only defences but also attacks. There is a legitimate presumption that Sam could create a military group, high-quality armed forces, that formed the core of his military force [6].

After Samo's death, his empire collapsed and the influence of the Avarian khaganate intensified. In the last quarter of the 7 th century, a certain Slavic and Avarian symbiosis was manifested, while the Slavic society was able to maintain its autonomous position [7]. Gradual Avarian assimilation was only one of the manifestations of development. On the other side, the strong pressure was on the Avarian khaganate by the Franconian Empire. In the years 791796, Avars suffered severe defeats in the battles among Charlemagne's armies, and Avarian power in the Carpathian area was rapidly being weaken. The latest report about Avars comes from the year 822 .

This development was mainly used by the Slavs, who gradually occupied the avarian positions. Against the background of the demise of the Avaris' estates, preconditions were created for the state-law process of the over-Danubian Slavs and Moravians.

The growing military power of the Slavs, coupled with the gradual liquidation of the Avaric domination, was a pretext for the military engagement of Karl the Great in the battles among the Slavs. The original avarian neighborhood of the Slavs caused the unification process, and probably military alliances. This increases the special position of the riding retainer as a guarantee of the position of the leading layer of society and of the basic part of the military organization [8]. Slavic ethnicity, in the beginning of the $9^{\text {th }}$ century, proved to be a vigorous element. Paradoxically, avarian oppression and interference of the Franconian Empire did not cause its extinction; on the contrary, in our area, in these dimensions, stronger alliances are created, opening up into the first nucleus of state system.

\section{Dimensions of the Development of External Security of Slavs in the Great Moravian Period}

In the process of gradual assimilation of the avarian ethnics in the Carpathian area and a stronger effort to expand of the Franconian Empire to the east, the Moravian and Nitrian princedom gradually came to the forefront. The power of the counties of course depended on their military power as the main attribute of the external and internal security of the territorial unit. In our environment, hillforts have begun to be built, with numerous functions related to production, trade, defence and to the organization of political power. From these settlements, the Slavic leaders of the most powerful governing layer could gradually consolidate their territory and strengthen their power.

The Middle Age timeliness of the written sources records a total of sixty-five military events related to the great Moravia. There are six references to internal divisions, sixteen references to the military expansion of Great Moravia, twenty-three to the defence of their own territory and eleven to the truce [9]. This calculation is definitely not definitive, it is assumed that not every event has been recorded by the author, or only a portion of the surviving sources are available from a number of irretrievably lost. Only the reports describing the merger of Nitrian with the Moravian Principality leading to the creation of Great Moravia in the year 833 can be interpreted as a competitive struggle between the two most powerful Slavic representatives of the present power. A similar character of the expansion is also evident from the 
conquerors battles against Vislans, Czechs and the Lusatian Serbs. This was probably an attempt to increase the number of exploited populations as a basic economic source along with the profit of agricultural land and material resources (eg. ores). The population of the same ethnicity can lead us to the idea that these disasters were easier or justifiable by improving the protection of their own territory, by increasing the military potential as well as by increasing the working capacity of the population. In any case, the dominion of such a territory became a source of instability and tension, and a power ruler could have taken advantage of the situation.

A similar instability was characteristic by the Great Moravian rulers themselves. The exiled Prince of Nitra, Pribina, fought (and apparently died in battle) against Mojmir's successor Rastislav. Rastislav, according to dramatic circumstances, was delivered by his nephew Svätopluk to the Franconian hands and died in prison.

Great Moravia gained a more stable position of the reign of Svätopluk I. when it became the Central European Power. Svätopluk was politically linked with the most important Czech prince of the Přemysl family. The peace treaty with Louis the German in the year 874, allowed him to conduct discharges into surrounding Slavic countries. Until the year 890 , he put under control the Vislan's princedom, took the rule over Bohemians, put under the control the Croats in Lower Silesia and the Wend Slavs. The princes were able to put up a relatively mighty military force into the fight - in the defence and in the outposts to foreign territory. The organizational basis was the main unit of the territorial economy and the military-political divisions - so called the castle system.

A military squadron was a stable military element with a relatively steady number of warriors. The owners of these cooperatives were economically supplied by the prince. One of the traditional rewards was the sharing of corrupts. Part of the retainers was placed as a permanently armed contingent in the castle centers. The second, potentially and, where necessary, a larger part of the armed forces was military alertness that consisted of the lower classes of the population [10]. The Great Moravia was rightly considered to be a major player in European politics at the time of Svätopluk's reign, the evidence is that it possessed a large number of armies. In order to ensure his position, Svätopluk took several spill-over operations into the area in order to break its supply or eliminate the space from which it could be threatened by the adversary. The Fuldean's annals tell us about his expedition into Pannonia in the year 884: "He had such a large number of people to see that his army was going through a spot from sun to dusk." [11]. Based on this record, the number of armies is estimated to be at least 25,000 foot troops and 8,000 cavalry along with supply wagons [12].

\section{The Internal Security Dimensions of the Slavs in the Great Moravian Period}

Besides the need to ensure external security, the stability of the Great Moravian society was primarily involved in ensuring internal order. The main attribute of enforcement was the armed power of the ruler, in this case his armed escort - the military squadron. It provided the oversight of the obligations of the population. They included donating "gifts" to the prince. It was basically about taking away part of the products of economic activity to ensure the life of the prince. Other duties included the building and maintenance of fortifications. We do not have many documents to use stable legal standards to ensure internal security. It is assumed that in Great Moravia there was a certain form of legal order based on ordinary law. With the progressive Christianization of the Slavic society, the principles based on Christian morality are gradually being applied. The Cyril and Methodius Mission represents not only the spreading of Christianity, but in 
connection with this process, the strengthening of the monarch's power is also tied up in intentions such as there is one Lord in heaven, so there is one Lord on earth.

It is obvious that the stability of Great Moravia has long been questioned, especially in the light of the fact that every competitive struggle of domestic Slavic powers became not only a cause but also a welcome means of interfering with its internal affairs by the East-Franconian Empire. It is necessary to emphasize that it was not just military interventions, but in the time of "peace" the efforts to penetrate into politics from East-Franconian clergy continued. A specific example is the attempt to discredit Archbishop Method, while Method's imprisonment was also criticized by Pope John VIII. [13].

In the craft of paganism, along with the expansion of Christianity in the Slavic population, there is a significant importance of a new power structure that equips clergy by legal codification. The document known as the Law of Judgment for the People (Zakon sudnyj ljudem) is considered as the oldest Slavic written monument. Originally, this document was classified as an oldRussian or old-Bulgarian written monument. The latest researches have shown its connection with the Cyrilmethodian mission, even though it has not been used in Great Moravia for too long. Svätopluk received through the Method special codex from Pope John VIII - socalled Extended Dioniziad [14].

In addition to the Judiciary Codex or the Dioniziad, period merchants and travelers also inform us about the legal customs and habits of the Slavs. These are much more attractive than legal articles that access specific examples of the usage of the law. For illustration, it is possible to state that the sentenced person was granted the exile punishment, respectively forced residence in a remote and unpopular region. This statement is derived from the testimony of Arab-Persian encyclopedist and geographer Abu Ali Ahmad ibn Umar ibn Rust, who writes in his book, The Book of Precious Titles (Kitab Al-A'alak and Nafísa), "If the thieves are caught in the kingdom of Slavs, their ruler send them to be hang out or send them to "Džira" - the most outlying province of his empire " [15]. According to J. Paulíni, this is a hardly identifiable title. P. Kónya gives one of the possible explanations, who describes the hilly area created by the accumulation of sandy sands in the central part of the Great Danube lowland, between the Danube and Tisa rivers on the territory of today's Hungary, according to the geographical characteristics of the historical territory of Hungary. This place was very poorly populated for its poor and barren soil until the beginning of the 10th century, but according to this it was called the "Džira". Moravians sent criminals there because for punishment. [16] The word "Džíra" could be explained as a backcountry place, so called the ideal place for the isolation of the antisocial elements. [17].

\section{Conclusion}

Slavic ethnic group has gone through a significant change since the establishment of the Slavs in our territory until the end of the Great Moravia. The basic dimensions of the development of the external and internal security of the Slavs in the pre-Moravian period was the decomposition of the tribal establishment running over against background the Avarian threat. The defense of their territory enters this process before the expansive policy of the French Empire. In the Great Moravian period, being culminant in the form of a state unit called in the historical sources as the Great Moravia, new sources were created for securing the safety - the systems of the hillforts as a center of defense, but also the administration of the territory and its own army with its external and internal role. The Slavic army itself was an important element in securing external security. Its elite part the military squad also played an important role in ensuring internal security. 
Obviously, this process was not straightforward. It was influenced by the destructive tendencies, in the form of an internal power struggle, which have been strengthened from outside to reach the political, ideological expansion.
Understanding and analyse of this process will help to complete the vision about the development of the society of our Slavic ancestors, who have become a compact part of European society and culture.

\section{References}

[1] Published in the edition: "Sources for Military History of Slovakia", In Slovak: Segeš, V., Šed'ová B., Pramene k vojenským dejinám Slovenska I/1, Bratislava, Vojenský historický ústav, 2010.

[2] Fusek, G., Najstaršie slovanské osídlenie Slovenska, In: Historická revue, No. 12, 2016, p.15.

[3] Majchút I., Hrnčiar M.: Measures and activities of the Slovak republic to reserve the current external security threats, In: Decisions in situations of endangerment : interdisciplinarity of the decision making process. Wroclaw : The General Tadeusz Kosciuszko Military Academy of Land Forces (MALF), 2017, p. 147.

[4] Segeš, V., Šed’ová B., Pramene k vojenským dejinám Slovenska I/1, p. 112.

[5] The term is temporaral because the Avarian threat has not been permanently removed by the military actions of the Sam's Empire. The destruction of the avarian domain occurred later, under the Charlemagne's expedition.

[6] Klučina, P., Člověk, zbraň a zbroj v obraze doby,Praha, Naše vojsko, 1984, p. 38.

[7] Segeš, V., Šed'ová B., Pramene k vojenským dejinám Slovenska I/1, p. 112.

[8] Klein, B., Ruttkay, A., Marsina.R. Vojenské dejiny Slovenska I, Bratislava, Ministerstvo obrany Slovenskej Republiky, 1993, p. 66

[9] ibid, p. 68

[10] Segeš, V., Šed’ová. B. Pramene k vojenským dejinám Slovenska I/1, p. 117.

[11] ibid, p. 222

[12] Choc. P, S mečem i štítem, Praha, Naše vojsko, 1967, p. 58-59

[13] Pope John VIII. in the letter to the Pontifical Legate, Bishop Paul instructs him to communicate with the Archbishop of Salzburg and the Passover Archbishop, and commits him to interpret them as follows: "You have convicted the bishop without a canonical sentence; ... you jailed and tortured him... he was three years repelled from the bishop's table. " In: Segeš, V., Šed'ová, B. Pramene $k$ vojenským dejinám Slovenska, p. 252.

[14] Segeš, V., Šed'ová. B. Pramene k vojenským dejinám Slovenska I/1, p. 117

[15] ibid, p. 270

[16] Kónya, P. a kol. Dejiny Uhorska, Prešov, Vydavatel'stvo Prešovskej univerzity, 2013, p.11.

[17] The word "Džíra" [đ̛̉i:ra] in east Slovakian dialects means "hole". In Slovak language this word is a synonym for ugly, dirty place. 